\title{
Loss of Control: Kaiser Wilhelm II, Mass Media, and the National Identity of the Second German Reich
}

\author{
Martin Koblrausch
}

The idea that particular political systems fitted specific nations or even expressed their character traits was well established around 1900. What did this idea imply for the institution of the monarchy in a period when both the monarchy and the idea of the nation were being redefined? This chapter will connect both processes for Germany. I will argue that only by highlighting the critical role mass media played as an 'ingredient' of an imagined new German monarchy, and as a means of comparing different systems of government in Europe, may we understand the relation between national identity and monarchy.

Therefore, this chapter will analyze how mediatization created new concepts of relating the monarch and the nation, but also created new expectations that the monarchy was unable to meet. Though the use of mass media helps to explain the dynamic redefinition of the relation between the monarchy and the nation in Germany, we cannot explain

\footnotetext{
M. Kohlrausch $(\bowtie)$

KU Leuven, Faculteit Letteren, Leuven, Belgium

(C) The Author(s) 2017

M. Banerjee et al. (eds.), Transnational Histories of the

'Royal Nation', Palgrave Studies in Modern Monarchy,

DOI 10.1007/978-3-319-50523-7_5
} 
this relation without considering the peculiar development of a national monarchy in Germany.

The monarchy in Germany had a long history and preceded the German nation state by some 1000 years. A German monarchy in the narrower sense, however, only emerged with the foundation of the new Reich in 1871. And even then the monarchy's constitutional status was far from clearly defined. While the newly created office of a German Emperor was formally only the title of the president of the Bundesrat, the federal assembly of the predominantly monarchical German states, the title elevated the existing Prussian monarchy and its Hohenzollern dynasty to national relevance. The Prussian king became automatically German Kaiser while the Prussian kingship remained his power base. On the surface this situation resembled the national role the house of Savoy acquired in Italy. However, the German situation differed in important ways. ${ }^{1}$ Underneath the new German Kaiser, 21 ruling dynasties remained in place, often representing centuries of monarchical continuity in large regions like Bavaria and extremely small entities like Reuss in Thuringia. ${ }^{2}$

Moreover, there was, at least in a certain historical reading, a German monarchy that was much older than any Prussian or Hohenzollern tradition: the Emperors of the Holy Roman Empire or old Reich, which had been ruled by the Habsburg dynasty almost continuously since the fifteenth century. This monarchy, with its universalistic ambitions, shifting dynastical basis, ambiguous territorial orientation, and multi-ethnic composition, could hardly be called a German monarchy in a nationalist sense. Consequently, for the dominant part of the German nationalist movement, the liberal Protestant strand, the old Reich embodied all the shortcomings that the new Reich had to overcome. Through liberal reforms in the 1870s, including a comparatively liberal press law of 1874 , it was in many respects transformed into an efficient and modern political entity and soon became a European and even global economic powerhouse.

In order to understand the challenge the German monarchy confronted, it helps to recall that the German Empire was not only called an Empire but, as recent historical research has stressed, also on many respects carried the traits of an empire. ${ }^{3}$ The diversity of different minorities posed considerable obstacles to national integration. The issue of national loyalty was fiercely debated in the national discourse of Imperial Germany, especially with regard to the substantial Polish minority. ${ }^{4}$ While the nation state had to be achieved internally, the new German Empire aspired to reach out 
beyond its borders. After the dismissal of Chancellor Otto von Bismarck in 1890, noteworthy parts of the German elite voiced their belief that Germany had to enter the race with the old and new empires in Europe and the Americas. Famously, Max Weber declared: 'We must grasp that the unification of Germany was a youthful spree, indulged in by the nation in its old age; it would have been better if it had never taken place, since it would have been a costly extravagance, if it was the conclusion rather than the starting-point for German power-politics on a global scale. ${ }^{5}$ Related hopes and expectations, soon popular under the signifier Weltpolitik, focused on the Emperor as the symbol of the Reich's political ambitions. ${ }^{6}$

Despite its dynamic economy, mighty military, and grandiose Weltpolitik schemes, the German empire remained a fragile construction. This was due to the enormous social tensions, reflected in the rapid and continuous rise of the Social Democratic Party, but also to the ongoing tension between dominant Prussia and southern Germany. In addition, the outward-looking forces in Southern Germany, parts of the Catholic West, and in formerly Polish territories in the East should not be underestimated. Like important parts of the working class, these milieux were not immune to a new popularized national agenda of an aggrandized Prussia, but were much more sceptical than other parts of Germany. ${ }^{7}$

In fact, addressing the president of the new federation with the vague title Kaiser could be seen as a compromise bridging these tensions. In defiance of all the historical burdens the title carried, it was also a rather modern notion. The title promised integration not yet achieved and allowed the federal princes to keep their titles and play their integrative role in the regions. ${ }^{8}$ In fact, despite its ancient origins, the office and the title of the German Emperor turned into the dynamic elements of the constitution. The Emperor was one of the few symbolic representations of the newfound unity. The expansion of the new nation states' political scope, into colonialism and naval policies for example, was closely connected to the emperor. Moreover, the office of the emperor served as an instrument for the personal integration of a scattered political landscape.

More by instinct than judgement, Wilhelm II replied to the expectations his office demanded. He expanded those aspects of the office of the Emperor his father already regarded as critical. Friedrich III, for all we know, would have stressed the supremacy of the Kaiser over the federal princes. He would also have elevated the Prussian court in Berlin to a German court if his reign had exceeded the 99 days before 
a fatal illness took his life. ${ }^{9}$ During Wilhelm II's reign, beginning in 1888, Kaiserreden (imperial speeches), Kaisertage (imperial days), and Kaiserwetter (the good 'imperial' weather, which was expected on these days) became household names, signifying the inroads the Kaiser's office had made into areas not explicitly foreseen in the constitution. ${ }^{10}$ The formerly somewhat modest court in Berlin became more glamorous but also socially encompassing and-with varying success-integrated the South German and Catholic elites. ${ }^{11}$ With the forced departure of Bismarck in 1890 and the subsequent introduction of the Weltpolitik, marking Wilhelm II's and Germany's aspiration to enter the imperialist race, dynasty and nation merged for the outside world. Thus it could be argued that in many respects Wilhelm II became the personification of the new Germany.

\section{Forging the Nation Through the Dynasty}

In order to understand why so many nationalist hopes were projected onto Wilhelm II in 1888 , one needs to recall the role the Hohenzollern dynasty played in the process of German unification. The dynasty profited from a growing perception that only strong monarchic leadership could achieve what the liberal-democratic movement of the 1848 revolution let slip away. This interpretation was particularly promoted after Wilhelm II came into power. His attempt to establish a cult around his grandfather Wilhelm I as Wilhelm the Great, the true founder of the Reich (with Chancellor Otto von Bismarck and Chief of Staff Helmuth von Moltke only in the position of helping hands), took things to the extreme. The manifold officially sponsored monuments for his grandfather were strikingly less popular in Southern Germany than in the Prussian-dominated north of the country. ${ }^{12}$ Still, it is hard to overestimate the influence of this officially sponsored fusion of dynasty and new nation state. The version of the 'German mission' of the Hohenzollern dynasty, which-contradicting a more critical reading of history-always strove to achieve a powerful Germany, came to dominate school books, national festivities, and the uncountable associations of veterans and other patriots. ${ }^{13}$ The unity of Germany and the Hohenzollern was celebrated throughout the country on 27 January, the Kaiser's birthday, an occasion which increasingly acquired the role of an official holiday. The celebration of the emperor's birthday not only signified a successful fusion of dynastic and 
nationalist programmes. These celebrations also marked the partially successful expansion of the originally rather technical idea of the Kaiser as a president into a true Reichsmonarch, a monarch representing the German nation. ${ }^{14}$

A more intellectual and academic discourse generally likened the monarchy as a form of government to the German people for historic reasons and as allegedly representing particularly well a specifically German idea of leadership, trust, and deliberate followership. ${ }^{15}$ The flip-side of this discourse was the perception of other forms of government as not only potentially less efficient but specifically un-German. This was certainly true for France, connoted with moral decay as well as a lack of organizational proficiency. The regime of Napoleon III was not only famously criticized by Karl Marx as Caesarism or Bonapartism, but critically used by those who believed Wilhelm II would take the new interpretation of the imperial office too far. ${ }^{16}$ After all, the combination of universal suffrage on the level of the Reich, an outspoken imperialism, and a flamboyant and self-assured monarch made comparison with the ill-fated emperor west of the Rhine a rather obvious matter. In 1900, the well-known theatre critic Alfred Kerr came to the conclusion: 'I'm not sure why it constantly appears to me as if Germany nowadays resembles the state of France under Napoleon III. In this time everybody succumbed to the imperial gloss and true characters were in short supply, and a delirium of an undefined nature grabbed the whole society.' ${ }^{17}$

While Kerr's statement targeted the extremes of Wilhelm II's style of government, the negative perception of French republicanism in general and Russian autocracy helped to establish an affirmative reading of the German model as superior. Interestingly, this critical assessment of foreign forms of governments increasingly also included the British system-that is a parliamentarian monarchy which for a long time the German elite had regarded as a model: "The times when our liberalism looked with admiration to the "mother of parliaments" are over for good. Our liberalism has fully broken with the mad assumption that the aristocratic oligarchy beyond the canal would be a democratic polity' one commentator concluded in 1912. ${ }^{18}$ Also reflecting a growing rivalry in international politics, German commentators complained that British parliamentarianism would only serve a small plutocratic elite. ${ }^{19}$ After 1900, only a few decision makers proposed a direct transfer of elements of French or British parliamentarianism. ${ }^{20}$ 


\section{The Monarch as the Anchor of a National Discourse}

It is, however, not sufficient to analyse the relation of dynasty and nation in Germany only in constitutional terms. There are good reasons to describe Wilhelm II as a media monarch who as such profoundly changed the perception but also the political and social role of the monarchy in Germany. ${ }^{21}$ This development had repercussions far beyond Germany as Wilhelm II came to personify the role model of a monarchy-be it positively or negatively perceived-throughout Europe and thus also forced the other European monarchs to react.

Around 1880, mass media in the modern sense emerged also in Germany. With the extremely high number of newspapers in Germany (as in other European countries) competition was fierce and not entering into the hot issues of critical political discourse was no longer an option, even for the conservative newspapers supporting government and state representatives.

At first glance, paradoxically, no other political institution was as much affected by the rise of mass media as the monarchy. This public comeback of the monarchy, an institution highly endangered only a few decades before, was caused by a number of reasons which were particularly pronounced in Germany. Popular monarchism centred around sentimental issues and focusing on the royal family had had a long tradition-it was now amplified by the mass reproduction of texts using new printing technology that allowed, in particular, new opportunities to print pictures of monarchs in a wide variety of publications.

Cinema became the most potent form of visualizing the monarchy, as it was particularly in tune with the visual programme the monarchy had to offer. In this the cinema exemplified a mechanism that also applied to postcards, illustrated journals, or other visual material. ${ }^{22}$ By 1900, Wilhelm II had become the most filmed person in the world. Consequentially, a number of leading international film companies celebrated Wilhelm as 'the most interesting personality ever caught by the lens of the cinematograph'. ${ }^{23}$ This reflected the remarkable fact that Wilhelm II came to personify a specific 'brand' in other European countries and even worldwide. When the peace activist Hermann Fried tried to win Wilhelm II over to his cause, he did so because he regarded him as 'the most famous individual on Earth'. ${ }^{24}$ Fried had probably come across an observation made by the literary critic Alfred Kerr in 1899: 'in the past ten years no-one in Europe 
has been discussed as much as he [the emperor] has'. ${ }^{25}$ More often than not, and certainly in times of international tension, the image of the Kaiser abroad was negative, but this was not necessarily so, not even in France. Kerr observed: 'A good listener will, in the course of a few weeks, hear more critical remarks on Wilhelm II in Germany than in France. Here [in France] one talks about him almost exclusively with esteem. One expects something of him. ${ }^{26}$

In the words of John Thompson, the 'transformation of visibility' in the nineteenth century served monarchs particularly well-from childhood on they were exposed like no one else to public scrutiny. ${ }^{27}$ Two characteristics of the monarchy played a decisive role here. First, the distinction from all other political actors through tradition and political power: strong iconic symbols - in Prussia/Germany the military iconography-were the prerogative of the royals. ${ }^{28}$ As attention spans became shorter and the media drifted from one story to another, these resources of visibility lifted monarchs, at least potentially, far above other politicians. If a monarch such as Wilhelm II also possessed a number of unmistakable features like his moustache or distinctive uniforms and helmets, they certainly helped his media affinity, even though they might have seemed ridiculous to some of his contemporaries. In an age of trademarks, the Kaiser became a particularly successful label; the advertising pioneer Ludwig Roselius called him an impressive early example of brand development: 'Propaganda needs a symbol, a flag, a focal point around which everyone can rally. [...] For the Islamic religion this is Mohammed, for the Social Democrats it is Liberty, Equality and Fraternity, for businessmen the brand-and for the German Empire it is the Kaiser. ${ }^{29}$

Second, European monarchs at the close of the nineteenth century profited from the personalization inherent in the DNA of mass media. ${ }^{30}$ The portrayal and reception of monarchs were prime examples of what Thompson called 'mediated intimacy', that is a personal interest in affairs far beyond one's immediate sphere. ${ }^{31}$ The enormous coverage of royal trivia illustrates this well. ${ }^{32}$ With the rapid expansion of the press for social, cultural, technical, and economic reasons around the 1880s, almost everyone could, and more often than not did, turn into a 'monarchy-expert'.

With the central political role attributed to Wilhelm II this mechanism was particularly pronounced in Germany. Tellingly, in Germany different intellectuals reflecting on what these changes meant for the monarchy observed that a Publikum, an audience, constituted itself vis-à-vis the monarch and substituted the Volk, the nation, of earlier times: 'The crowns are 
today not endangered by the heroic but the trivial [...]. The people turned into an audience, and this audience demands comedies in which the Prince only pretends to be a hero. ${ }^{33}$ Newspaper comments increasingly entered a meta-level, discussing the effect of certain monarchical actions or aspects of the personality of royals on monarchic sentiment rather than assuming a natural unity of prince and people or nation. Indeed, we cannot separate the political dimension of the monarchy from its public dimension. Political relevance formed the basis for the visibility of monarchs and for the interest of the media. How far political acting was commented upon, and thus amplified, in the media, and how far the media created new scope or restrictions for political action depended on the constitutional prerogatives of monarchs. But also the monarch's personality and personal concept of rule played an important role. Again, this was no exclusively German phenomenon, but it is important to recall decisive differences between countries' constitutions and political cultures.

Also, in Victorian Britain, often seen as an ideal example of a secluded monarchy, the media demanded a strong public presence from the royal family. ${ }^{34}$ Moreover, something which is often forgotten on the continent, British engineers of monarchism in the Victorian age, from Prince Consort Albert to Benjamin Disraeli, advocated a stronger monarchy in reaction to the rise of mass society and media: ${ }^{35}$ 'Public opinion has a more direct, a more comprehensive, a more efficient organ for its utterance, than a body of men sectionally chosen,' Disraeli had one of the figures in his novel Coningsby explain in $1844 .{ }^{36}$ The revival of the monarchy is here directly linked to new opportunities offered by the press, first developed on a new scale in Britain. ${ }^{37}$ Both in Britain and Germany, as well as in many other European countries, it became more of a structural development that the monarch was exposed in the media than a matter of personal preference and decision.

In Germany, such ideas could gain more concrete grounding with the strong political role the German Kaiser had as Prussian king and supreme warlord, but also as the focal point of traditions and new unificatory expectations. Journalist Maximilian Harden, though a strong critic of Wilhelm II, wanted to preserve the monarch as a politically influential player and polemicized against turning the monarch into a 'Dalai Lama in uniform'. ${ }^{38}$

It is striking to note how early on and in a radical way both the new influence of the mass media and its consequences for politics were reflected by journalists. They understood that a monarchy covered intensely and increasingly without inhibition in the press would transform into a new 
institution. Wilhelm II was expected to find and establish a societal consensus using the new media means at his disposal. ${ }^{39}$ Political thinkers and many newspaper commentators explained that, now that mass media was within reach for almost anyone, it should also become the preferred mode of political communication. With the monarch setting the political agenda, the public sphere discussing his proposals, and the monarch channelling its conclusions into the political machine, a new powerful mechanism seemed at hand. This mechanism promised at the same time to be democratic, fast, and effective, in short 'modern' and superior to political systems elsewhere. Given the central role the media played in this imagined new form of political communication, it is unsurprising that journalists eagerly endorsed the model of a direct exchange between monarch and people. ${ }^{40}$ While the liberal politician Friedrich Naumann addressed Wilhelm II as 'Signalperson', setting the agenda of the political discussion, ${ }^{41}$ more critical commentators insisted on the Kaiser's duty to listen more carefully to his people: 'Only if the Emperor mingles himself with the people, when he exchanges the uniform with civil cloth, when he takes the feelings and demands of his people into account positive change will be possible. ${ }^{42}$ Former US President Theodore Roosevelt noted with some disappointment during his stay in Germany in 1909, 'that both the men highest in politics and the administration, and the people at large, took evident pleasure in having him [Wilhelm II] understand that he was not supreme, and that he must yield to the will of the Nation on any point as to which the Nation had decided views'. ${ }^{43}$

In this understanding, but also to some extent in reality, the monarchy became a programmatic institution, aligning itself with causes such as welfare, the fleet, or colonialism. In particular the latter two projects obsessed the nationalist camp and were ideally suited to align the dynasty and the great things the German nation was to achieve in the future. This fusion of interests was not only achieved by concrete measures, but through an intense discourse in which the Kaiser often functioned as the one setting the tone. After all, Wilhelm II was the first German monarch to use political speeches to rally the people behind his political programme. ${ }^{44}$ These Kaiserreden's strong catchphrases suited the needs of the new mass media. The Kaiser's speeches regularly set the parameters of national debates, as the monarch aspired to a decisive role in shaping political consensus in an increasingly complex society. That the Kaiser's speeches were excessively criticized does not diminish their significance, but rather underlines the importance that contemporaries attributed to them. 
The increasingly critical reception of the speeches, in particular after the turn of the century, reflects not only their often controversial content, but also marks the collapse of the idea of the monarch as a moderator of national discourse. Tellingly, this crisis regularly emerged along the fault-lines of the national and the dynastical. There were risks involved for the monarchy in such intense media coverage, characterized by the eschatological dimension of a media-driven programmatic monarchy with its high-flying goals associated with the monarch, and the almost boundless scrutinizing of the monarch's person, who after the turn of the century featured in hundreds of caricatures. The famous scandals centring around the German Kaiser between 1906 and 1909, the Eulenburg scandal addressing allegedly homosexual courtiers, and the Daily Telegraph affair (the printing of Wilhelm II's diplomatically damaging statements), are not conceivable without the developments described. But they also reflect a growing uneasiness on the part of large sections of the German people over what they regarded as being in the national interest. At the height of Anglo-German tension and the ensuing crisis of Wilhelm II's monarchy in the Daily Telegraph affair even conservative newspapers began questioning the monarch's national loyalties: 'The German Kaiser should not be the personal friend of England or any other power but he should be the friend of the German nation. ${ }^{45}$

In the two scandals the press applied clear parameters for performance on the royal stage. Aspects of the relation of monarch and mass mediasuch as which newspapers the monarch read or how his advisors channelled the communication between monarch and people-came to be seen as essentially political issues. ${ }^{46}$ The scandals, damaging as they had been for the monarchy and in particular for the personal reputation of Wilhelm II, reconfirmed the relevance of the communicative space emerging around the monarch in Wilhelmine Germany. In some respects the monarchy's now apparently overstretched position stemmed from the very tension between well-developed participatory demands and a more sober monarchic reality. Content wise, both scandals expressed the uneasiness of a new right with what it regarded as the meagre results of the goals which stood central in Wilhelm II's programmatic monarchy. While the journalist Harden, originally with rather liberal convictions, accused Wilhelm II of softness in his dealings with France, the nationalist camp in particular attacked the Kaiser's alleged closeness to Britain-being the son of a British princess and grandson of Queen Victoria — and as being both nationally unreliable and an inefficient advocate of German interests. ${ }^{47}$ 
While the argument that an 'audience' supplanted the people vis-à-vis the mediatized monarch certainly has something to it, it obscures the fact that this very audience was still nationally defined. The scandals, however, also raised doubts about the assumed superiority of the German monarchical model, as one newspaper remarked: 'The pride on the moral quality of our public life, which we have in mind when normally looking self-assured down on the degeneration of the leading circles in France and England, has been put into question. We see disdainful, sickly effeminate men who were part of the national leadership or at least stood close to it. ${ }^{48}$

Scandals accentuated the advantages and disadvantages of different political systems and the national overtones they came with. Scandals intensified comparisons, but even now, only a few voices presented the United Kingdom as an example. Harden, in contrast to earlier statements now held affirmatively that 'there are signs that the position of our monarchy will come close to the English one' ${ }^{49}$ However, the influential intellectual Ernst Horneffer phrased the opposition to this idea in lengthy words:

The German Emperor reduced to an empty formula, only a trimming of the German state? This would mean to neglect the very meaning of the German past, the spirit of a tradition of more than a thousand years. I must admit, if only out of defiance, I do not like to recommend the English ideal as the goal of our development. ${ }^{50}$

Others even argued that the English monarchy, which gained influence under Edward VII, and the strong role President Roosevelt played in the USA, would prove the need for a strong monarchy in Germany 'because we think modern'. ${ }^{51}$

\section{The Limits of National Integration Through The Dynasty}

Of course, in a European situation in which it was more the norm than the exception that ruling dynasties from Belgium and the Netherlands to Bulgaria and Rumania did not originate from the countries they ruled, national loyalty to the dynasty was sometimes controversial within the context of rising nationalism. ${ }^{52}$

But in Prussia and Germany, at least in its northern part, where generally little doubt as to the national credentials of the Hohenzollern dynasty prevailed, the problem was of a different order. ${ }^{53}$ The dynasty was charged 
with achieving internal social integration and with finding a strong position for Germany in a globalizing world. Wilhelm II accepted these tasks and set himself ambitious goals. The tensions arising from entrusting the monarch with a national agenda were aggravated, and to a certain extent caused, by the fact that the monarch provided the very communicative space in which new hyperbolic nationalist demands could be voiced. If we take a closer look at those groups voicing a new nationalist agenda going beyond what the Empire under Bismarck had achieved, we find numerous pamphleteers, journalists who earlier on had invested considerable energy in defining a newly styled monarchy. ${ }^{54}$ Interestingly, those who had phrased such demands soon moved from criticizing certain actions of the monarch to questioning the very assumption of the monarchy, at least in its form at the time, as the type of government most in line with the traditions and particularly the needs of the new nation state.

Initial calls for the need for a true Führer, a leader of the nation, were voiced in the course of the Eulenburg scandal. The term leader was so popular also because it could refer both to the monarch or an alternative, no longer dynastically legitimized, contender. ${ }^{55}$ Yet, in both cases the term referred to a leader of the nation, a political figure whose legitimacy was derived from the followership of the nation. Briefly before the First World War, the well-known historian Friedrich Meinecke declared ambivalently: 'We demand a leader for whom we may walk through the flames. ${ }^{56}$ Hermann Oncken, also a historian, addressed the emperor at the same time as 'Leader of the nation', who would stand 'right in the glaring light of the day $[\ldots]$ at every moment visible and sought-after, observed and criticized, loved and reproached'. ${ }^{57}$ Heinrich Class' book Wenn ich der Kaiser wär (If I Were the Emperor) had a whole chapter on the theme 'Der Kaiser als Führer' ('The Emperor as Leader'). ${ }^{58}$ The monarch could be a leader, but, as a growing strand of right-wing commentators stressed, he was only accepted under the assumption that he would justify the trust placed in him through political achievements. The notion of the Fübrer entailed the assumption that followership was voluntary and could be withdrawn as soon as the monarch no longer served the needs of the nation. Already in addressing the monarch as a leader, the shortcomings of the reigning monarch were stressed. The notion of the leader as a political alternative to the monarch was bound to the notion of the nation's precedence over the ruler and dynasty. The pan-German right wing publicist Ernst von Reventlow, one of the fiercest critics of the Kaiser, expressed this sharply in 1906. Wilhelm II, he argued, acted too 
much as a 'Dynast', a dynastic ruler, and not, as Edward VII in Britain, preferentially in the national interest. Von Reventlow lamented: 'Edward VII travels as representative of his nation and acts in her interest, quasi on behalf of her, while in the case of Wilhelm II the dynastic element is decisive. ${ }^{59}$ Another commentator positively described Edward as the 'secret Emperor of England'. ${ }^{60}$

A much discussed pamphlet of the same year argued that the nation had the right to 'push aside' the Hohenzollerns without breaking the law if it no longer felt adequately represented. The future, the pamphlet's author who certainly did not belong to the left camp, argued, would belong to democracy. ${ }^{61}$ As another commentator added in 1909, pomp and glamour of the court had distracted the emperor from his people. Yet there was, he argued, not only a rule by divine right but also a rule by the right of the people (Volksgnadentum). ${ }^{62}$ It was this new right which claimed democracy on national grounds, which challenged the Wilhelmine monarchy more directly after 1900 than the 'classic' social democratic threat. The challenge of the right was aggravated by the fact that it proved more difficult to suppress criticism from the right than from the left.

The uncoordinated attempts to answer this sort of critique by connecting the monarchy even more with the symbols of Weltpolitik hardly sufficed. On the contrary, these attempts elevated tensions in international politics considerably and exposed the monarchy to even more criticism. ${ }^{63}$ It would be too easy to see the path to the First World War sketched out here. But the fact that in the decisive weeks and months of 1914 Wilhelm II was apparently neither willing nor any longer able to follow a more dynastic logic instead of what he apparently perceived as a national logic is rather evident. His quote 'I know no parties anymore, I know only Germans!' of 4 August 1914 in front of the Reichstag, ${ }^{64}$ regarded as perhaps the most successful of his uncounted sound bites, thus also included the Kaiser himself.

In 1913, briefly before the Great War, the Austrian writer Carl Techet held: 'The future menacing with the most dreadful struggles does not seem to embody a threat for the Princes but rather strengthens their position. ${ }^{65}$ But it was doubtful what would happen if decades of accumulated hatred would collapse on Europe. After all, the peoples had lived and sacrificed for nation and fatherland, not for their princes. Though the German monarchy survived four years of extreme warfare, indeed none of the dynasties, including the Hohenzollerns, would survive still ruling or in power by the end of the struggles and German defeat. 


\section{Conclusion: The European Dimension}

This chapter has stressed the specifics of the German monarchy, stemming from the tensions caused by the late establishment of a German nation state, and between political integration via the monarchy and the radicalization of German nationalism, but it has also suggested that these can only be understood in a transnational context. Of course, the notion of a specifically German model of monarchy only made sense when it was distinguished from other models associated with foreign countries. On the other hand, the structural changes to which the German monarchy reacted, such as the rise of mass media and political mobilization, were of a transnational order.

Historiography on nineteenth- and twentieth-century monarchies through a comparative perspective have always been foremost a history of constitutional differences. Even while acknowledging that political reality and constitution might differ considerably, this historiography still stressed qualitative differences between limited, constitutional monarchies like those in Britain or Belgium, and the more autocratic monarchies of Russia, Austria, and also Germany. Focusing on the relation of mass media and monarchy allows for a more complex picture, without doing away with the unquestionable implications the constitutional prerogatives had. The high expectations created through mediated communication between the traditional ruler and a modern public offered potential for disillusionment, but might also have served as a bridge to forms of political leadership which could do without dynastic legitimacy. In its alliance with the national movement, the Hohenzollerns, and Wilhelm II in particular, were simultaneously forging and competing with this movement. The figure of the Kaiser was the focal point for national loyalty and served indirectly to create a space for national political communication. At the same time, and relatedly, the (democratic) potentials unleashed pointed beyond the dynasty. In the long run, the monarchy lost out. It did so due to the dramatic gap between Wilhelm II's national visions - the glorious times ('herrlich[e] Tag[e]') he promised-and the many shortcomings of his political performance. ${ }^{66}$ But it also lost out because the German monarchy had to align itself more closely with an extremely dynamic national movement. Moreover, the immense integrative needs of the only recently unified and internally diverse German nation, which were partially projected onto the monarchy, overburdened the institution. 
Was this thus a specifically Germany story? For the reasons given, the answer needs to be nuanced. After all, the monarchy placed itself and was placed-much more than other political institutions-in a European framework of comparison. ${ }^{67}$ Attention on the German Kaiser was widespread outside Germany as well, albeit often with differing connotations. The fact that as soon as the First World War started the dynasty was pushed to the background reflected the ruler's inability to meet these expectations. But this fact also reflected the rise of a new, more radical nationalism. This strand of national identification questioned more decisively what the ruler had achieved for the nation. Ernst Jünger, the famous nationalist chronicler of the German front experience, for example, demanded that the monarch stand the test in military action himself. ${ }^{68}$ Indeed, after the war, such comments escalated in the intense and long debates on Wilhelm II's 'desertion' and national betrayal. ${ }^{69}$ Unsurprisingly, the topic of Wilhelm II's 'international descent' was also raised again by the nationalist camp and served as a confirmation that the Kaiser allegedly had never really felt nor acted as a German. ${ }^{70}$

During the First World War the Germans began to doubt quickly if Wilhelm II was still an adequate representative of their nation. In many respects, Hindenburg soon took over the public role of the monarch. The entente camp, however, did not hesitate about how to personalize the German enemy. This happened predominantly, and apparently effectively, through visually evoking the Kaiser. Thousands of caricatures, songs, and pamphlets portrayed a bearded monster with an eagle helmet, the Beast of Berlin, as an American film had it, and thus combined national characteristics and the dynasty more effectively than the Kaiser was ever able to do. Advertising lines like 'An Amazing Exposé of the Intimate Life of the Mad Dog of Europe' (for the film The Beast of Berlin) do not only testify to the dynamics of war propaganda but also to the global celebrity status of Wilhelm II, which was a precondition for the effectiveness of such propaganda. Overall, this combination reflected the transnational mechanisms in which an authoritarian monarchy was perceived not only as a symbol, but a logical consequence, of the detested German character. ${ }^{71}$

When, in 1917, the famous author H. G. Wells published his booklet In the Fourth Year, a staunch plea for erecting an anti-imperialist League of Nations to end the war and forestall future wars, he added a chapter on 'The Future of Monarchy'. He argued that the German Kaiser had not only unleashed the war, but had destroyed the 'Teutonic' monarchic system-based on marriages of families of mostly German descent-that 
had dominated Europe throughout the nineteenth century. This system, he argued, was meant to maintain peace, but was structurally unable to do so due to its ties to German authoritarianism. As a consequence, Wells demanded a complete 'Anglicization' of the dynasty in Britain-which had rebranded itself 'Windsor' during the war-as a precondition for its survival: 'The security of the British monarchy lies in such a courageous severance of its destinies from the Teutonic dynastic system.' After all, Wells underlined, 'We have fought in this war for Belgium, for France, for general freedom, for civilization and the whole future of mankind, far more than for ourselves. We have not fought for a king. ${ }^{72}$

Wells' argument re-emphasizes the need to understand the nationalization of dynasties and the influence of dynasties on nation building as a process that was not confined to a single country. This chapter has shown, for the example of Kaiser Wilhelm II, how the establishment of a mediatized monarchy generated a specifically intense fusion of the nation and dynasty. The dynamics unleashed in this process could not be controlled by the monarch and decisively contributed to the end of the monarchy in Germany.

\section{Notes}

1. For the Italian example, see Chap. 3 by Amerigo Caruso in this volume.

2. For a particularly illustrative example, see Werner Greiling and Hagen Rüster (eds) (2013), Reuß älterer Linie im 19. Jabrbundert. Das widerspenstige Fürstentum?, Jena.

3. Edward Ross Dickinson (2008), 'The German Empire: An Empire?', History Workshop Journal 66, 129-62.

4. Robert Spät (2014), Die 'polnische Frage' in der öffentlichen Diskussion im Deutschen Kaiserreich, 1894-1918, Marburg.

5. Max Weber (1988), Gesammelte politische Schriften, ed. by Johannes Winckelmann. Tübingen, 26, cited from Max Weber, Selections in translation, ed. by W.G. Runciman, Cambridge 1978, 266.

6. Elisabeth Fehrenbach (1969), Wandlungen des deutschen Kaisergedankens (1871-1918), München, Wien, 28, 30-1; Frank Lorenz Müller (2011), Our Fritz. Emperor Frederick III and the Political Culture of Imperial Germany, Cambridge Mass., 88-92. 
7. Werner K. Blessing (1979), 'Der monarchische Kult, politische Loyalität und die Arbeiterbewegung im deutschen Kaiserreich', in: Gerhard, A. Ritter (ed.), Arbeiterkultur, Meisenheim, 185-208.

8. Martin Kohlrausch (2005), Der Monarch im Skandal. Die Logik der Massenmedien und die Transformation der wilhelminischen Monarchie, Berlin, 26-33.

9. Müller (2011), 88-104.

10. See Thomas A. Kohut (1991), Wilhelm II and the Germans. A Study in Leadership, New York, Oxford, 127-31.

11. Martin Kohlrausch (2008), 'Zwischen Tradition und Innovation. Das Hofzeremoniell der wilhelminischen Monarchie', in: Andreas Biefang, Michael Epkenhans, and Klaus Tenfelde (eds), Das politische Zeremoniell im Kaiserreich, Bonn, 31-51.

12. Reinhard Alings (1996), Monument und Nation. Das Bild vom Nationalstaat im Medium Denkmal - zum Verhältnis von Nation und Staat im deutschen Kaiserreich 1871-1918, Berlin, New York.

13. Thomas Rohkrämer (1990), Der Militarismus der 'kleinen Leute'. Die Kriegervereine im Deutschen Kaiserreich 1871-1914, München; Peter Sprengel (1991), Die inszenierte Nation. Deutsche Festspiele 1813-1913, Tübingen.

14. Fritz Schellack (1988), 'Sedan- und Kaisergeburtstagsfeste', in: Dieter Düding, Peter Friedemann, and Paul Münch (eds), Öffentliche Festkultur. Politische Feste in Deutschland von der Aufklärung bis zum Ersten Weltkrieg, Reinbek, 278-297; Frank Bösch (2008), 'Das Zeremoniell der Kaisergeburtstage', in: Andreas Biefang, Michael Epkenhans, and Klaus Tenfelde (eds), Das politische Zeremoniell im Kaiserreich, Bonn, 53-76.

15. Dieter Groh (1972), 'Cäsarismus, Napoleonismus, Bonapartismus, Führer, Chef, Imperialismus', in: Otto Brunner, Werner Conze, and Reinhart Koselleck (eds), Geschichtliche Grundbegriffe. Historisches Lexikon zur politisch-sozialen Sprache in Deutschland I, Stuttgart, 726-71, here 764-71.

16. Karl Holl, Hans Kloft, and Gerd Fesser (2001), Caligula - Wilhelm II. und der Cäsarenwahnsinn. Antikenrezeption und wilhelminische Politik am Beispiel des Caligula von Ludwig Quidde, Bremen, 68, 108.

17. Alfred Kerr (1997), Wo liegt Berlin? Briefe aus der Reichshauptstadt, ed. by Günther Rühle, Berlin, 564 . 
18. Lookout (1912), 'Englands Weltherrschaft und die deutsche Luxusflotte', Berlin, 8, quoted in: Christian Fälschle (1991), Rivalität als Prinzip. Die englische Demokratie im Denken des wilhelminischen Deutschland 1900-1914, Frankfurt/Main, 180. For the more and more negative perception of Britsh parliamentarism see: Christoph Schönberger (1997), Das Parlament im Anstaltsstaat. Zur Theorie parlamentarischer Repräsentation in der Staatsrechtslehre des Kaiserreichs (1871-1918), Frankfurt/Main, 282-3 and 291-3.

19. For the general mechanism of 'reading' the other country through the Emperor: Lothar Reinermann (2001), Der Kaiser in England. Wilhelm II. und sein Bild in der britischen Öffentlichkeit, Paderborn; Jan Rüger (2011), 'Revisiting the Anglo-German Antagonism', Journal of Modern History 83/3, 579-617.

20. Mark Hewitson (2001), 'The Kaiserreich in Question: Constitutional Crisis in Germany before the First World War', Journal of Modern History 73, 725-80, 726.

21. The arguments expressed in the following paragraphs are partially based on my article, Martin Kohlrausch (2010), 'The Workings of Royal Celebrity: Wilhelm II as Media Emperor', in Edward Berenson and Eva Giloi (eds), Constructing Charisma: Celebrity, Fame, and Power in Nineteenth-Century Europe, New York, 52-66.

22. Eva Giloi (2007), 'Royally Entertained: Visual Culture and the Experience of Monarchy in Wilhelmine Prussia', Intellectual History Review, 17, 203-24.

23. Martin Loiperdinger (1997), 'Kaiser Wilhelm II.: Der erste deutsche Filmstar', in: Thomas Koebner (ed.), Idole des deutschen Films, Munich, 41-53.

24. Alfred Hermann Fried (1905), Kaiser werde modern!, Berlin, 5.

25. Alfred Kerr (1997), Wo liegt Berlin? Briefe aus der Reichshauptstad, Berlin, 496.

26. $\operatorname{Kerr}(1997), 497$.

27. John B. Thompson (2000), Political Scandal. Power and Visibility in the Media Age, Cambridge, 33-40.

28. Martin Kohlrausch (2009), 'Der Mann mit dem Adlerhelm. Wilhelm II. - Medienstar um 1900', in: Gerhard Paul (ed.), Bilderatlas des 20. und beginnenden 21. Jahrhunderts, vol. 1, Göttingen 2009, 68-75. 
29. Gerhard Voigt (1975), 'Goebbels als Markentechniker', in: Fritz Haug (ed.), Warenästhetik. Beiträge zur Diskussion, Weiterentwicklung und Vermittlung ibrer Kritik, Frankfurt/Main, 231-60, here 234.

30. See Franziska Windt, Jürgen Luh, and Carsten Dilba (2005), Die Kaiser und die Macht der Medien, Berlin, 67-76.

31. Thompson (2000), 40.

32. Richard Williams (1997), The Contentious Crown. Public Discussion of the British Monarchy in the Reign of Queen Victoria, Aldershot, 7.

33. Otto Julius Bierbaum (1907), Prinz Kuckuck. Leben, Taten, Meinungen und Höllenfahrt eines Wollüstlings, Munich, 590 and 595; Rudolf Borchardt (1908), 'Der Kaiser', Süddeutsche Monatshefte, 5, 1908, 237-52, here 240, 247; Thomas Mann (1909), Königliche Hoheit, Berlin 1909, 258.

34. Williams (1997) 14, 32-4. Generally: John Plunkett (2003), Queen Victoria. First Media Monarch, Oxford.

35. Antony Taylor (1997), 'Down with the Crown'. British Antimonarchism and Debates about Royalty since 1790. London, 28.

36. Benjamin Disraeli (1844), Coningsby, or the New Generation, Oxford, 266.

37. Plunkett (2003), 115. For Germany: Monika Wienfort (1993), Monarchie in der bürgerlichen Gesellschaft. Deutschland und England von 1640 bis 1848, Göttingen, 163.

38. Maximilian Harden (1992), 'Monarchen-Erziehung', Die Zukunft 1, 625-32, 630 a.

39. See Kohlrausch (2005), 73-83.

40. Martin Kohlrausch (2010), 'Die Politik der Medien. Der Aufstieg der Massenmedien und das politische System in Deutschland und Großbritannien um 1900', in: Ute Daniel and Axel Schildt (eds), Massenmedien im Europa des 20. Jahrhunderts, Köln, 305-30.

41. Friedrich Naumann (1909), 'Das Königtum III', Die Hilfe 4 , 48-50.

42. Aristides (1909), Der Kaiser und die Nation. Leipzig, 7.

43. Roosevelt to the British historian Sir George O. Trevelyan, 1911, quoted in: Ragnhild Fiebig-von Hase (2003), 'The uses of "friendship". The "personal regime" of Wilhelm II and Theodore Roosevelt, 1901-9', in: Annika Mombauer and Wilhelm Deist (eds), The Kaiser. New Research on Wilhelm II's Role in Imperial Germany, Cambridge, 143-75, here 158. 
44. Friedrich Wilhelm IV used speeches, but not in the political sense as Wilhelm II did. See the manifold examples in Michael A. Obst (2010), 'Einer nur ist Herr im Reiche'. Kaiser Wilhelm II. als politischer Redner, Paderborn.

45. Der Reichsbote, 29. Oktober 1908.

46. Kohlrausch (2005), 238-43.

47. Kohlrausch (2005), 226.

48. Rheinisch-Westfälische Zeitung, 27. Oktober 1907.

49. Maximilian Harden (1908), 'In usum delphini', Die Zukunft, 62, 73-7.

50. Ernst Horneffer (1909), 'Der Kaiser und die Nation III', Die Tat, I, 5, 279-291, 285.

51. Karl Kormann (1909), 'Zum 50. Geburtstag des Kaisers', Akademische Blätter, 23, 353-55, here 353.

52. Dieter Langewiesche (2013), Die Monarchie im Jahrhundert Europas. Selbstbehauptung durch Wandel im 19. Jabrhundert, Heidelberg.

53. For the background, see Manfred Hanisch (1989), 'Nationalisierung der Dynastien oder Monarchisierung der Nation? Zum Verhältnis von Monarchie und Nation in Deutschland im 19. Jahrhundert', in: Adolf M. Birke and Lothar Kettenacker (eds), Bürgertum, Adel und Monarchie. Wandel der Lebensformen im Zeitalter des bürgerlichen Nationalismus, München, 71-91.

54. See the examples in Kohlrausch (2005), 290-301.

55. Yves Cohen (2013), Le siècle des chefs. Une histoire transnationale du commandement et de l'autorité, Paris. Moritz Föllmer (2014), Leadership in Modern Times - Reflections on Yves Cohen's Le siècle des chefs', International Journal for History, Culture and Modernity, 2/1, 65-81.

56. Friedrich Meinecke (1913), 'Deutsche Jahrhundertfeier und Kaiserfeier', Logos 4, 161-75.

57. Hermann Oncken, Der Kaiser und die Nation, Heidelberg 1913, 16.

58. Daniel Frymann (i.e. Hinrich Class) (1912), 'Wenn ich der Kaiser wär'. Politische Wabrheiten und Notwendigkeiten, Leipzig.

59. Ernst von Reventlow (1906), Kaiser Wilhelm II. und die Byzantiner, Berlin, 39.

60. Rudolf Martin, Kaiser Wilhelm II. und König Edward VII, Leipzig 1907,31 . 
61. Anonym (1906), Unser Kaiser und sein Volk. Deutsche Sorgen. Von einem Schwarzseher, Freiburg, Leipzig, 85.

62. Aristides (1909), 5.

63. Jan Rüger (2007), The Great Naval Game. Britain and Germany in the Age of Empire, Cambridge.

64. Speech of Emperor William II for the Opening of the 2nd Session of the Reichstag, 4 August 1914, in: (1916) Verhandlungen des Reichstags. XIII. Legislaturperiode, II. Session, vol. 306, Stenographische Berichte, Reichstagsprotokolle, Berlin, 2, http:// www.reichstagsprotokolle.de/Blatt_k13_bsb00003402_00013. html, accessed 4 October 2016.

65. Carl Techet (1913), Völker, Vaterländer und Fürsten. Ein Beitrag zur Entwicklung Europas, München, 441.

66. Speech on the occassion of the Brandenburg Provincial Diet, 24 February 1892, cited from Johannes Penzler (ed.) (1897), Die Reden Kaiser Wilhelm II. in den Jabren 1888-1895, vol. 1, Leipzig, 208-9, here 209.

67. Daniel Schönpflug (2013), Die Heiraten der Hohenzollern. Verwandtschaft, Politik und Ritual in Europa 1640-1918, Göttingen; Johannes Paulmann (2000), Pomp und Politik. Monarchenbegegnungen zwischen Ancien Régime und Erstem Weltkrieg, Paderborn.

68. See e.g. Ernst Jünger (1922), Der Kampf als inneres Erlebnis, Berlin, 52.

69. Kohlrausch (2005), 346-61.

70. Erwin Wulff (1918), Die persönliche Schuld Wilhelms II. Ein zeitgemäßer Rückblick, Dresden, 40-2.

71. See the manifold telling examples in Paul van Damme (2013), Vriend over Vijand. De Grote Oorlog in Spotpringen, Tielt.

72. Herbert George Wells (1918), In the Fourth Year, London, 86-95. 